\title{
COVID-19 pandemic: report on the use of auriculotherapy to optimize emergency workers' health
}

\author{
Pandemia COVID-19: relato do uso de auriculoterapia na otimização da saúde de trabalhadores de urgência
}

Pandemia COVID-19: informe sobre el uso de auriculoterapia para optimizar la salud de los trabajadores de emergencia

\section{Rosiane Lopes Trigueiro',11 \\ ORCID: 0000-0001-9542-7864 \\ Açucena Leal de Araújo' \\ ORCID: 0000-0002-0100-0147 \\ Thereza Maria Magalhães Moreira' \\ ORCID: 0000-0003-1424-0649 \\ Raquel Sampaio Florêncio' \\ ORCID: 0000-0003-3119-7187}

' Universidade Estadual do Ceará. Fortaleza, Ceará, Brazil. "Secretaria de Saúde do Ceará, Serviço de Atendimento Móvel de Urgência. Fortaleza, Ceará, Brazil.

How to cite this article:

Trigueiro RL, Araújo AL, Moreira TMM, Florêncio RS. COVID-19 pandemic: report on the use of auriculotherapy to optimize emergency workers' health.

Rev Bras Enferm. 2020;73(Suppl 2):e20200507. doi: http://dx.doi.org/10.1590/0034-7167-2020-0507

Corresponding author:

Raquel Sampaio Florêncio

E-mail: raquelsampy@hotmail.com

EDITOR IN CHIEF: Dulce Barbosa ASSOCIATE EDITOR: Alexandre Balsanelli

Submission: 05-14-2020

Approval: 09-07-2020

\section{ABSTRACT}

Objective: To report the use of auriculotherapy to optimize emergency workers' health during the COVID-19 pandemic. Methods: Experience report of auriculotherapy application in 48 workers of a mobile emergency care service center located in a city in the Northeast of Brazil. Results: Six auriculotherapy sessions were held, each lasting eight minutes, based on specific protocols in the area and Chinese energy physiology. The aim of the practice was to contribute to the improvement of physical (pain) and emotional (anxiety, stress) symptoms, and the promotion of greater health and willingness to work. In addition, the experimentation of this practice was thought of as a pilot for the creation of a care service for workers. Final considerations: In the report of auriculotherapy, the description of its application and its positive and negative points in relation to professionals working in the pandemic scenario were considered and its continuity was requested.

Descriptors: Auriculotherapy; COVID-19; Pandemics; Urgency; Nursing.

\section{RESUMO}

Objetivo: Relatar o uso de auriculoterapia na otimização da saúde de trabalhadores de urgência durante a pandemia da COVID-19. Métodos: Relata-se a experiência de aplicação da auriculoterapia em 48 trabalhadores de uma base do serviço de atendimento móvel de urgência situada em uma cidade do Nordeste brasileiro. Resultados: Realizaram-se seis sessões de auriculoterapia, com duração de oito minutos cada, com base em protocolos específicos da área e da fisiologia energética chinesa. A prática visou contribuir com a melhora dos sintomas físicos (dor) e emocionais (ansiedade, estresse), maior promoção da saúde e aumento da disposição para o trabalho. Além disso, a experimentação dessa prática foi pensada como um piloto para a criação de um serviço de cuidado ao trabalhador. Considerações finais: A auriculoterpia foi relatada, levando em consideração a descrição da sua aplicação e seus pontos positivos e negativos em relação aos trabalhadores atuantes no cenário pandêmico, sendo requisitada sua continuidade.

Descritores: Auriculoterapia; COVID-19; Pandemias; Urgência; Enfermagem.

\section{RESUMEN}

Objetivo: Informar el uso de auriculoterapia para optimizar la salud de los trabajadores de emergencia durante la pandemia COVID-19. Métodos: Informe de experiencia de aplicación de auriculoterapia en 48 trabajadores de un centro de servicio de emergencia móvil en una ciudad del nordeste de Brasil. Resultados: Se realizaron seis sesiones de auriculoterapia de ocho minutos cada una, basadas en protocolos específicos en el área y fisiología energética china. El objetivo fue mejorar los síntomas físicos (dolor) y emocionales (ansiedad, estrés), mayor promoción de la salud y disposición al trabajo. Además, se pensó en la experimentación de esta práctica como un piloto para la creación de un servicio de atención a los trabajadores. Consideraciones finales: En el informe de auriculoterapia, se tuvo en cuenta la descripción de su aplicación y sus puntos positivos y negativos en relación a los profesionales que trabajan en el escenario pandémico y se solicitó continuidad de la terapia.

Descriptores: Auriculoterapia; COVID-19; Pandemias; Urgencia; Enfermería. 


\section{INTRODUCTION}

In late December 2019, Wuhan, a city in China, registered a condition of pneumonia caused by the coronavirus Sars-CoV-2 called COVID-19. The outbreak of the disease led the World Health Organization (WHO) to declare a state of public health emergency of international interest in January 2020 and, on March 11, to declare the disease a pandemic. Until May 11, 215 countries were affected by COVID-19 worldwide, with 4 million people infected, more than 280 thousand deaths and a lethality rate of $6.8 \%{ }^{(1)}$.

On February 26, 2020, the first case of Covid-19 was registered in Brazil, the first country in Latin America that registered the outbreak, currently with more than 162 thousand people infected and 11 thousand deaths. In this context, the state of Ceará stands out as one of the most affected ${ }^{(1-2)}$. The main problem of Covid-19 is the large number of serious cases with severe viral pneumonia commonly seen in urgency and emergency cases, and often progressing to treatment in Intensive Care Units (ICUs). The exponential and pandemic transmission of Sars-Cov-2 also generated a lack of personal protective equipment (PPE) worldwide $^{(3)}$. Furthermore, since this is a new disease, there are still no vaccines for its prevention, drugs that cure it and in-depth knowledge about the disease, generating great insecurity in workers in health centers ${ }^{(1)}$, especially in those working in urgency/emergency, such as in the Mobile Emergency Care Service (Portuguese acronym: SAMU).

Added to this scenario, are the extensive workloads to which these professionals have been subjected, with the illness and even death of several co-workers. This whole context has brought them a feeling of helplessness and even the absence of institutional support that generate psychological suffering ${ }^{(3)}$, including the fear of infecting other people, especially their family ${ }^{(4)}$.

Reports of depression, anxiety, insomnia, anguish and even psychological exhaustion in these workers, which were not rare in a context prior to the pandemic, have been exacerbated by it $^{(4-5)}$. Thus, the use of Integrative and Complementary Health Practices (ICHP) as an enhancing therapy of care has been recognized and incorporated by the Brazilian National Health System (Brazilian SUS) $^{(6-7)}$.

Among ICHP, auriculotherapy (branch of Acupuncture) stands out for its short, medium, and long term effects on people's health, as well as being easy to apply. It includes the mechanical stimulation of specific areas of the auricular pavilion, as the ears have reflex points that correspond to all organs and bodily functions. When these points are stimulated, a series of phenomena in the brain that assist in the healing process are triggered. Thus, auriculotherapy promotes analgesia and treats different physical and psychological conditions. Its benefits are already proven in the reduction of levels of stress and anxiety, thereby promoting an improvement in quality of life ${ }^{(8)}$. In contexts of crisis, such as that experienced by everyone and especially health workers, the need for this therapy is clearly perceived, given all its benefits.

\section{OBJECTIVE}

To report the use of auriculotherapy to optimize the health of emergency workers during the COVID-19 pandemic.

\section{METHODS}

This is an experience report. It was conducted from April to May 2020 with the application of auriculotherapy to workers of the Mobile Emergency Care Service in the fight against COVID-19 in a center located in a city in Ceará, northeastern region of Brazil.

Ceará is one of the states hardest hit by COVID-19. It has more than 31,000 suspected cases, 18,000 confirmed cases, 185 of its municipalities were affected and the capital, Fortaleza, has the highest concentration of confirmed cases and deaths (90\%) of the state $\mathrm{e}^{(2)}$.

Currently, the service has 102 workers, of which 48 participated in the meetings for application of auriculotherapy. The technique was applied to nurses, doctors, technicians and nursing assistants, and employees of the administrative sector, general services and emergency response telephone operator.

In total, there were six meetings; one with each participant. Each session lasted eight minutes, on average. At the beginning of each session, the technique of the Chinese thinking on the health/disease process was explained, the materials used were presented and guidance on the care after fixation of the micropore was provided. The participant was asked about any symptoms that hindered the performance of daily activities in this pandemic period and, based on the answer, the five points common to all individuals were Shenmen, Kidney, Autonomous Nervous System - ANS, Lung and Spleen.

The meetings took place in the library of the institution with a special ambience, colored lights, relaxing music and a diffuser with lavender essential oil; and in private rooms, as some people could not be absent of the service. People served in private rooms were not offered this differential of chromotherapy, music and aromatherapy because these environments were not suitable. Everyone in the service used PPE, regardless of the sector. Workers were contemplated with the technique on Tuesdays and Fridays, the days the specialist was on duty.

\section{FINDINGS AND DISCUSSION}

The findings and discussion were described in three moments: the search for workers and description of the materials used for the application of auriculotherapy; the course of the auriculotherapy application process; and the positive and negative points of the use of auriculotherapy observed by the professional who applied the technique, who is also active in the frontline of COVID-19, as reported below.

\section{In search of pandemic workers and description of the material used}

Workers of the Mobile Emergency Care Service, including health professionals working there, have reported greater physical and emotional stress after the growing expansion of COVID-19 in Ceará. The already numerous demands and assignments before the pandemic have increased dramatically in number and intensity. Thus, reports of fear, peaks of anxiety, insomnia, migraines, muscle pain (especially in the shoulders, neck, chest and lower back), heartburn, rhinitis, physical discomfort, pain in the knees, higher levels of stress and the feeling of physical exhaustion began 
to mark the daily lives of members of the Mobile Emergency Care Service. This context provided conditions for the application of auriculotherapy as a form of care for these professionals.

The promotion of care for health service workers or those contributing to these services is indispensable nowadays, as good outcomes depend mainly on healthy work teams. Thus, aiming at optimizing quality of life, improving sleep and daily disposition, reducing pain, physical exhaustion, anxiety and stress, and promoting a state of balance for these workers, the ancient Chinese practice of auriculotherapy began in a space provided by the Mobile Emergency Care Service, where all the necessary material was gathered.

There was an active search for workers during their rest time and in the service base yard. Some professionals spontaneously sought auriculotherapy sessions at the recommendation of other workers or by invitation previously made by the researcher.

Auriculotherapy has a proven effect, the materials for its performance are low cost and hypoallergenic, as they are composed of yellow mustard seeds, micropore adhesive tape, 70\% alcohol, cotton, procedure gloves, surgical mask, tweezers and table for quick preparation of the system. Its disadvantage is being a little-known technique, commonly associated with esotericism that suffers from the disbelief of many people in Western society. The institution supplied the materials they had available, such as procedure gloves, cotton, 70\% alcohol (liquid and gel). The other materials were purchased with the researcher's own resources (Figure 1).

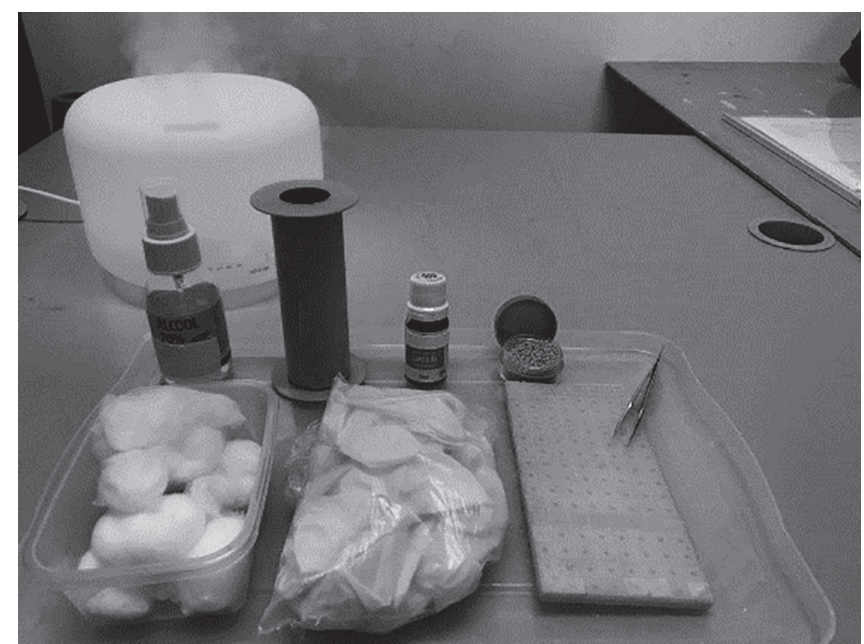

Figure 1 - Materials used for the application of auriculotherapy

The use of therapeutic methods to care for workers fighting COVID-19 is necessary to promote and restore their health ${ }^{(4)}$, especially when the only requirement is the appropriate and easily accessible material. The aim of auriculotherapy was to contribute to improve the health status of these workers thus, care with this Chinese therapy was gradually started for employees of the service. It was a challenge to introduce an effective oriental therapy in a commonly technical, skeptical environment with a notably western vision.

\section{Auriculotherapy in the fight against the pandemonium of the pandemic}

People went to the service library for the sessions and were individually invited to sit in chairs at a distance of approximately
1.50 meters between them. They were also asked to wait for their turn for assistance, wore a surgical mask and, while waiting, participated in an initial moment of meditation guided by the psychologist.

The specialist in Chinese technique, who works in the service and at the Central of Regulation of Urgencies, started her activities wearing gloves at all times (changed at each service), in addition to a surgical cap and a mask changed every two hours. The patients' ears were cleaned with $70 \%$ liquid alcohol. In the room, there was a multicolored reflector and a diffuser containing lavender essential oil, while playing music at $528 \mathrm{Hertz}^{(7)}$. The step by step of the entire process was explained to participants for their greater safety and understanding of the therapy (Figure 2).

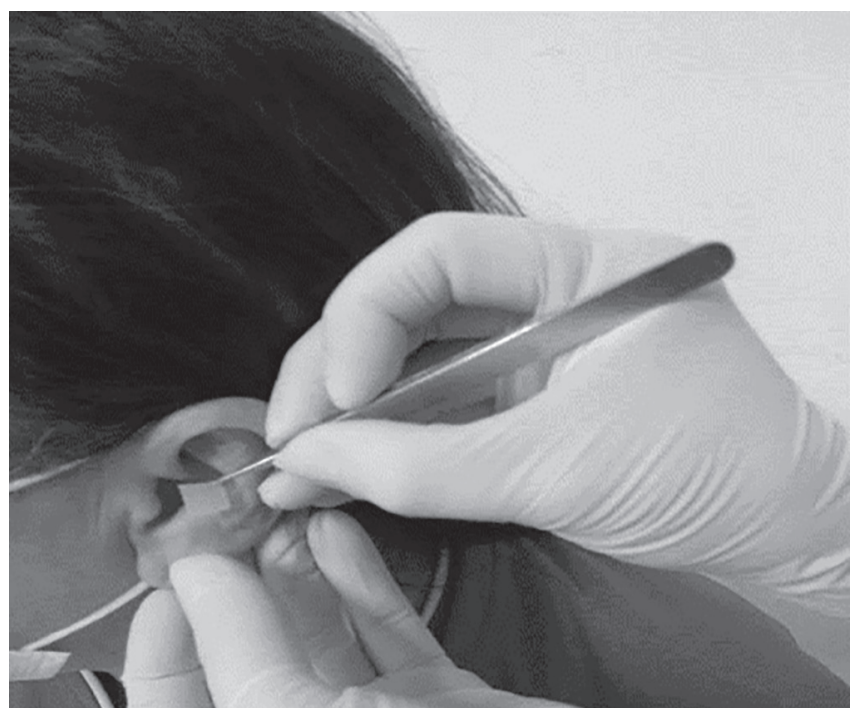

Figure 2 - Application of auriculotherapy

In this context, the combination of the two techniques lasted, on average, 30 minutes. After the therapy was performed on everyone, there was a brief explanation about the need to maintain the seeds placed in the ear throughout the week. All were invited to continue therapy on their shift days, if they so wished.

Despite the benefits brought by the therapy, it is also necessary to provide a description of the technique, of auriculotherapy and its principles hence, this was incorporated into the sessions. The therapy should be more widespread and presented to the population in order to resolve doubts and suspicions.

In general, according to the traditional Chinese Medicine, the food and beverages we ingest will give rise to the so-called essential Qi, a type of energy essential to life. After it passes through the Stomach and Spleen meridian, it will be transformed into nutritious Qi in the Lung and sent to the Heart, and through the blood vessels, will pass nourishing all the organs that make up Zang Fu; and in defensive Qi which, as the name says, will defend our organism from external attacks ${ }^{(7)}$. In male patients, the right ear was chosen to start the treatment because it represents yang and, in women, the left ear because it represents Yin ${ }^{(8)}$. Thus, the Cybernetic Triangle points, together with those of the Lung and Spleen were chosen for the service protocol.

The Cybernetic Triangle is composed of the Shenmen, Kidney and Sympathetic points placed in this order as the opening of 
the treatment. It is used mainly and respectively to predispose the trunk and cerebral cortex to receive and decode the reflexes of the next points; stimulate the filtration of blood through the kidneys to release toxins and improve circulation; and regulate the neurovegetative system by stimulating the functions of the sympathetic and parasympathetic, providing general balance of the organism and acting on the muscular system, causing anti-inflammatory and relaxing action ${ }^{(8)}$.

The stress inherent in the Mobile Pre-Hospital Care itself contributes to the onset of physical and mental changes of professionals working in the service. Together with the pandemic period, came the work overload and the need to work double shifts as a result of COVID-19 symptoms among professionals, in addition to the fear of becoming infected and contaminating family members. In addition, the fear of leaving the service due to contamination and losing work shifts due to the weak work bond in the form of cooperatives, lower earnings due to leave and loss of bonuses, cancellation of scheduled vacations and even of current vacation periods (statutory employees) are some of the reasons contributing to higher stress levels in this public and consequent physical and psychological disorders ${ }^{(9)}$.

Auriculotherapy originated thousands of years ago in China and is an integral and appropriate system for the treatment of different diseases, as already mentioned. There are studies demonstrating its effectiveness in improving several general psychophysical conditions $^{(9)}$ and post-traumatic stress ${ }^{(10)}$. This reinforces auriculotherapy as an important strategy for workers in the fight against coronavirus, because it helps them to cope with the processes of psycho-emotional suffering and stressors repeatedly exacerbated during the pandemic. Its fast, safe and non-invasive applicability make it a feasible health-promoting strategy nowadays and in crisis contexts.

Given the above, the implementation of auriculotherapy in the current pandemic context of COVID-19 represents a measure to alleviate physical and emotional conditions. Since this is an ancient, evidence-based technique of rapid application and low cost, it expands the means of care and therapeutic possibilities and constitutes an ally in the care of people currently facing the COVID-19 pandemic ${ }^{(9)}$.

\section{Warding off the evil: from pandemic stress to health pro- motion of the Mobile Emergency Care Service workers}

From the objectives outlined in relation to auriculotherapy for each worker, such as the improvement of physical and psychological symptoms, immunity and self-care, workers spontaneously made thankful reports. In addition, there was a closer relationship with co-workers during the sessions, strengthening bonds by the (re)construction of support networks in times of COVID-19.

The application and management of this therapy to workers of the Mobile Emergency Care Service was deemed successful and its continuity was encouraged, since the physical and psycho-emotional consequences of COVID-19 can extend to periods subsequent to the end of the pandemic ${ }^{(4)}$. Participants and the specialist who applied the technique recommended the institutionalization of the integrative therapy service. Integrative and Complementary Health Practices are a set of heterogeneous strategies of practices, products and knowledge grouped by the common characteristic of not belonging to the scope of knowledge and practices recognized in conventional medicine. They expand the means of care and therapeutic possibilities and constitute an ally in the care of people who currently face the COVID-19 pandemic.

Such experience brought as positive points: the strengthening of bonds; better ambience; better service provided by professionals, as those working without pain and with a good quality of sleep become more productive; contribution to management for making the employee feel cared for and embraced by the service; the feeling of empowering and helping co-workers in their physical and emotional conditions.

The following negative points were observed: impossibility of embracement of all professionals in the service, given the specialist's workload; absence of a specific place to perform the therapy; lack of service advertisement; absence of an institutionalized service to care for professionals.

The specialist promoting the therapy was able to perform the interventions as planned, with minor adaptations in relation to the location, when necessary. The experience encouraged the creation of a service that promotes the health of workers of the Mobile Emergency Care Service, and its report was considered a pilot project.

\section{Study limitations}

Limitations of the study lie in the difficulty of initially attracting workers. In addition, the fact of this being an oriental therapy from China, a country where the pandemic also originated and that has suffered rejection of its products because of the population's lack of knowledge about how long the virus can remain active on objects.

\section{Contributions to the fields of Nursing, Health}

The experience report can instigate other specialists to implement auriculotherapy sessions in health services. In the context of the Mobile Emergency Care Service, the therapy was able to improve the willingness to work and favor the coping with the pandemic, which may have generated less absenteeism and peri and post-traumatic stress. In addition, providing care to those who organize supplies and care for patients in this pandemic is a relevant point to favor the immunity of those who have daily risked their lives and those of their families in the current health context.

\section{FINAL CONSIDERATIONS}

In the report of auriculotherapy, the description of its application, its relationship with the pandemic and its positive and negative points related to professionals working in the pandemic scenario were considered. The therapy has potential to contribute to coping with physical and psycho-emotional situations of workers fighting the COVID-19 pandemic. Participants requested the maintenance of auriculotherapy sessions in the current and the post-pandemic context, as the latter may also prove challenging.

\section{ACKNOWLEDGEMENTS}

Thanks to workers of the Mobile Emergency Care Service. 


\section{REFERENCES}

1. World Health Organization. Coronavirus disease (COVID-19) Pandemic [Internet]. 2020 [cited 2020 May 10]. Available from: https://www. who.int/emergencies/diseases/novel-coronavirus-2019

2. Ministério da Saúde (BR). Boletim epidemiológico novo coronavírus (COVID-19 [Internet]. IntegraSUS. 2020 [cited 2020 May 10]. Available from: https://indicadores.integrasus.saude.ce.gov.br/indicadores/indicadores-coronavirus/coronavirus-ceara

3. Asmundson GJG, Taylor S. Coronaphobia: fear and the 2019-nCoV outbreak. J Anxiety Disord. 2020;70:102196. doi: 10.1016/j. janxdis.2020.102196

4. Rajkumar RP. COVID-19 and mental health: a review of the existing literature. Asian J Psychiatr. 2020;52:102066. doi: 10.1016/j. ajp.2020.102066

5. Mehta M, Singh MM, Gupta SK, Kushal A. Study of Stress among Health Care Professionals: A Systemic Review. Int J Res Found Hosp Healthc Adm. 2018;6(1):6-11. doi: 10.5005/jp-journals-10035-1084

6. Sousa IMC, Tesser CD. Medicina Tradicional e Complementar no Brasil: inserção no Sistema Único de Saúde e integração com a atenção primária. Cad Saude Publica. 2017;33(1):e00150215. doi: 10.1590/0102-311x00150215

7. Sionneau P. A essência da medicina chinesa: retorno às origens. São Paulo: EBMC; 2015. 493 p.

8. Souza MP. Tratato de Auriculoterapia. Brasília: Copyright; 2013. 358 p.

9. Luo, H., Tang, Q., Shang, Y. et al. Can Chinese medicine be used for prevention of Corona Virus Disease 2019 (COVID-19)? a review of historical classics, research evidence and current prevention programs. Chin J Integr Med. 2020;26;243-50. doi: 10.1007/s11655-020-3192-6

10. Kwon C-Y, Lee B, Kim S-H. Effectiveness and safety of ear acupuncture for trauma-related mental disorders after large-scale disasters. Medicine (Baltimore). 2020;99(8):e19342. doi: 10.1097/MD.0000000000019342 